\title{
PURSUING: A GROUNDED THEORY OF TOURISM ENTREPRENEURS' \\ UNDERSTANDING AND PRAXIS OF SUSTAINABLE TOURISM
}

SANDIE KENSBOCK* $*$ and GAYLE JENNINGS*

*Department of Tourism, Leisure, Hotel and Sport Management, Griffith University.

\begin{abstract}
Tourism entrepreneurs are recognised as instigators of much tourism development and consequently have a role to play in contributing to sustainable tourism. In particular, entrepreneurial engagement with sustainability has the potential to alleviate negative impacts of tourism on a micro scale, particularly socio-cultural consequences, environmental degradation, and economic inequalities. This study used a grounded theory approach to determine sustainable tourism meanings and practices undertaken by tourism entrepreneurs operating on the Gold Coast of Queensland, Australia. The study is significant as the grounded theory of pursuing, which emerged, highlights connectivity between the entrepreneurial self, the actions of entrepreneurs, their use of ethics and their praxes of sustainable tourism.
\end{abstract}

The significance of this study is threefold. First, it contributes to the body of qualitatively informed holistically-focused tourism studies. Second, it contributes to the literature related to entrepreneurs, sustainable tourism and ethics. Third, the study highlights the lived experiences of tourism entrepreneurs pursuing the provision of 
sustainable tourism enterprises. In particular, the tourism entrepreneurs identified the factors, which served to circumvent their pursuit of sustainable tourism.

KEYWORDS: Tourism Entrepreneurs, Sustainable Tourism, Grounded Theory

[Word count: 173] 


\section{INTRODUCTION}

This paper presents a grounded theory model of pursuing. The model provides insights into the lived experiences of seven tourism entrepreneurs on the Gold Coast, Queensland, Australia and their understandings and practices regarding sustainable tourism. Specifically, pursuing is a social process wherein the entrepreneurial self of tourism operators pursues information, legitimacy and futurity through social interaction in order to frame sustainable tourism and its implications for their entrepreneurial practices.

Tourism entrepreneurs were selected as the focus of this study because entrepreneurs are recognized as major instigators of business in the tourism industry, as well as substantial shapers of development (Glover, 1998; Honey, 2003). Relatedly, tourism entrepreneurs are believed to be the key to the conflict of interest in common pool resource use, and ultimately sustainable tourism (Buckley, 2002; Chapman, 2000; Hemingway, 2005; Holden, 2005; Thompson, 2004; Wempe, 2005). Subsequently, research focusing on such topics from industry perspectives provides important insights into relationships associated with sustainable tourism (Morrison \& Teixeira, 2004). Bearing this issue in mind, this study sought to develop a theoretical explanation of seven tourism entrepreneurs' lived experiences, understandings and commercial practices associated with sustainable tourism. The participating tourism entrepreneurs were involved in the accommodation, restaurant, transport, tour, attraction and event based sectors on the Gold Coast in the state of Queensland, Australia.

\section{BACKGROUND}

Tourism entrepreneurs have been major instigators of nodal tourism development in the Gold Coast region. These entrepreneurial tourism developments have provided significant 
contributions to a critical mass of tourism facilities and provided vigor for the Gold Coast to develop into Australia's premier seaside mass tourism destination (Russell \& Faulkner, 2004). The Gold Coast region has been a tourist destination since the 1880 s, and the area hosts major national and international events, and provides theme parks, wildlife sanctuaries, world-class golfing greens, and an international airport (Gold Coast Tourism, 2009). In 2007/2008 the Gold Coast region hosted 9.6 million visitors, incorporating domestic, international and day visitors that contributed over $\$ 3.09$ billion to the local economy (Gold Coast Tourism, 2009). The Gold Coast region has also experienced many of the negative impacts of tourism (Hollinshead, 1988; Weaver \& Lawton, 2001). These negative impacts have been identified globally as detrimental socio-cultural impacts (Haley, Snaith \& Miller, 2005; Faulkner \& Tideswell, 1997), environmental degradation (Buckley, 1996), and creation of economic inequalities (Wilkinson, 2007). Such impacts have direct consequences for sustainable tourism and tourism entrepreneurs, who are instigators of tourism development and stakeholders in sustainable tourism.

\section{SUSTAINABLE TOURISM}

As a western concept, a number of interpretations of sustainable tourism have been expressed. In saying this, it must be recognized that in other cultures, peoples of the world have long practiced living in harmony with earth's resources. Towards the end of twentieth century, global advocacy of sustainable tourism emerged from a realisation that negative impacts of tourism development were limiting sustainability of the tourism industry (Holden, 2003). Although there are a number of definitions of sustainable tourism, the most accepted definition is the one from the World Tourism Organization, WTO. The WTO (1995) defined sustainable tourism as that which "meets the needs of present tourists and host regions while protecting and enhancing opportunity for the 
future" (http:www.wto.org). Other definitions emphasize variously that sustainable tourism incorporates economic viability with care for the environment and future resource capacity preservation, intra and inter-generational equity, and satisfaction of basic needs for all members of society (Bramwell \& Lane, 2002; McCool \& Lime, 2001). Tourism and sustainability inevitably link to business. For example, Lepoutre and Heene (2006) identified a range of antecedents associated with operating a sustainable tourism business: "issue characteristics, personal characteristics, organizational characteristics and context characteristics”. (p.257). Branco and Rodrigues (2006) identify the pillars of sustainability at the business level, as economic creation of wealth, efficient environmental management and protection, and social philanthropy. Patterson, Bastianoni and Simpson (2006) and Holden (2003) highlight tourism's sensitivity and contribution to climate change. They specifically identify the incongruity of opposing business versus environmental concerns, while Welford, Ytterhus and Eligh (1999) identify tourism entrepreneurs as having significant potential to direct sustainable tourism development. Therefore, this study sought to provide a business sector perspective of tourism entrepreneurs' understanding of sustainable tourism.

\section{ENTREPRENEURIALISM}

In determining how to define a tourism entrepreneur, extant literature was reviewed. This review revealed an extensive and diverse literature with a great deal of debate and analysis, yet entrepreneurs' actions appear enigmatic. Kuratko (2006) identifies 44 English language refereed academic journals within the field of entrepreneurship. Collectively, this literature reveals a great deal of research from various disciplines, theoretical frameworks and methodological approaches, including economic science, psychology, sociology, and 
business management (Dery \& Toulouse, 1996; Hill \& McGowan, 1999; Hisrich \& Peters, 1998; Montanye, 2006). However, there is an absence of consensus over a definition of an entrepreneur, reflecting the complexity and diversity of entrepreneurial behaviour (Landstrőm, 2005). Baumol (2004) notes two uses of term entrepreneur: as someone who creates, organises and operates a new business, and alternatively, as the innovator who transforms inventions into economically viable entities. In light of conflicting interpretations associated with 'entrepreneur', a working definition was developed. Based on an examination of the literature and adapting Baumol's (2004) definition, the authors posit that 'tourism entrepreneur' refers to 'an individual who creates a business with some component of originality in provision of a product, service, or experience for tourists'. The study question 'what are tourism entrepreneurs' lived experiences, understandings and practices of sustainable tourism?' framed the nature of this research as exploratory and interpretive. To match this frame, a subjective, interpretative perspective was chosen for this study, which was guided by qualitative grounded theory methodology.

\section{APPROACHES TO TOURISM RESEARCH}

There have been numerous calls for qualitative methodological approaches in studies of tourism and entrepreneurship research (Becken \& Patterson, 2006; Lynch \& MacWhannell, 2000; Pearce, 2001). Font and Harris (2004) believe that qualitative empirical material is meaningful to broaden our understanding of sustainable tourism. Use of innovative, interpretive methodologies is also advocated as a way forward to encompass the complexity of tourism (Hollinshead \& Jamal, 2007; Jennings, 2001). Grounded theory is regarded as a method and a methodology that is particularly suited to an exploratory and interpretive frame. Grounded theory refers to both an innovative approach to developing 
explanatory theoretical ideas, as well as a specific set of tools for inductive and deductive analysis of empirical material to construct conceptual understandings of the studied phenomena (Charmaz, 2006).

\section{GROUNDED THEORY}

Grounded theory was developed by Barney Glaser and Anslem Strauss (1967). Their original approaches and later modifications by Glaser and Strauss (and Corbin) have been critiqued for being objectivist in nature. To counter this, Charmaz (2006) proposed a constructionist grounded theory assuming multiple realities based on an epistemology of co-creation of understanding, assuming the researcher's involvement in the research process. Jennings and Junek (2007) observe that grounded theory offers tourism studies the potential to generate holistic theories, and an understanding of human behaviour that is not readily quantifiable. Analysis of empirical material in this study followed the central tenets of grounded theory's explicit method (Glaser, 1978, 1992, 1998, 2001, 2007) rather than Charmaz's (2005) constructivist and more recent constructionist approach (Charmaz, 2006). This decision was made in order for the authors to use the original tenets of grounded theory and thereafter make their own critiques informed by practice of the approach as well as any modifications.

\section{Grounded theory and sampling}

In this study, the use of Glaser's approach included 'theoretical sampling' (Glaser, 1978). This is a purposive sampling technique that enables selection of information rich and relevant sources that provide informed empirical materials (Patton, 1990). Purposive sampling does not attempt to generate a representative sample set. Instead it involves selection of informed participants who fit the study definition of 'tourism entrepreneurs'. 
Purposive sampling enabled participation of seven entrepreneurs from diverse tourism ventures. These entrepreneurs were selected following an initial determination that they had started businesses with some component of originality in provision of a product, service, or experience for tourists. Additionally, they could be classified as some of the 'movers and shakers' (Russell \& Faulkner, 2004) of the Gold Coast tourism industry. Individually each possessed a well-established reputation as demonstrated in a review of mass media sources where they were conspicuous by their repeated presence in the regional newspaper, the Gold Coast Bulletin, and local television Channel 9 GC News. In this study, all of the entrepreneurs were men and had variously been involved in creating a commercial tourism enterprise based on their experiences through many years of involvement in hospitality as vintners, hoteliers, chefs or travel facilitators. Empirical material was collected during one-on-one semi-structured interviews (Jennings, 2005). These interviews ranged in duration of one to two hours and were held at varied times according to the entrepreneur's schedule at locations convenient to each of the entrepreneurs. Each interview commenced with a grand tour question regarding the nature of the entrepreneur's enterprise and then moved onto questions framed around sustainability and its role within each of the enterprises. See Figure One.

\section{[INSERT FIGURE ONE ABOUT HERE]}

As with any qualitative study the 'findings' are grounded in the lived experiences of the seven Gold Coast tourism entrepreneurs, who participated in this study. Like other qualitative studies, it is socially, culturally and temporally bounded by the study participants, the setting and temporal frame. In this instance, seven tourism entrepreneurs operating on the Gold Coast of Australia in the first decade of the twenty-first century. To 
ensure rigor in the study's 'findings', Lincoln and Guba's (1985) tenets of credibility, transferability, dependability and confirmability were applied. In particular, credibility was established through 'goodness of fit' that is, how well the model resonated with the co-constructors of the studied realities, the tourism entrepreneurs via participant checking. Participant checking involved the researcher discussing the interpretations with participants who gave feedback regarding resonance of the interpretations with their meanings and practices. Transferability is associated with the pursuing model resonating with other tourism entrepreneurs. Dependability refers to design stability (grounded theory methodology), and confirmability incorporating quality through use of a reflexive journal and adherence to ethics approvals, memoing and crystallization through participant checking.

\section{Grounded theory interpretation}

The interpretation of empirical materials through constant comparison of codes identified in semi-structured interviews generated a theoretical model of pursuing. Pursuing is a basic social process of action related to understanding the participant tourism entrepreneurs' practice of sustainable tourism in the context of the diverse and complex Gold Coast tourism industry. Practice here means generic processes that tourism entrepreneurs engaged in rather than discrete operational strategies at a day to day level. Glaser (1992) describes a basic social process as a theoretical summary of the systematic patterned flows of social life. The theoretical categories of pursuing were generated through inductive generation of concepts supplemented with deductive reasoning. Basic

social processes incorporate components of context, which is an overriding condition under which sets of related categories occur. Other component categories of basic social processes are conditions, which are synonymous with qualifiers and link causes (sources, 
reasons or explanations) to consequences (outcomes, efforts results). All of these categories associate with a central core category with contingent elements as well as relationships that connect these components. In this study, a basic social process model of pursuing emerged to explain the seven tourism entrepreneurs-participants' understanding and practices of sustainable tourism.

The interpretation of empirical materials in this study outlined an intricacy of action and interaction that coalesced around a core category of pursuing related to tourism entrepreneur's understanding sustainable tourism (see figure 2). Pursuing was instigated by each of the tourism operators' entrepreneurial self. The process of pursuing was predicated on several simultaneous and inter-dependent conditions rather than a sequential portrayal of action. These conditions include pursuing information, legitimacy and futurity. All of which may be considered determinants of actions. These interconnecting conditions were contingent on the tourism entrepreneurs' lived experiences of social interactions involving ethical decision-making related to sustainable tourism. These interactions were complex and multi-dimensional in nature and were associated with intervention, mitigation, alteration, or facilitation of the tourism entrepreneur's pursuit of sustainable tourism practice. The following section deconstructs the pursuing model for readers.

[INSERT FIGURE 2 ABOUT HERE] 
The core category, pursuing, reflects the tourism entrepreneurs' lived experiences in the tourism industry and encompasses their actions as they consider sustainable tourism and its practice. The term pursuing is used instead of entrepreneurial 'drive', which is acknowledged by many authors in literature (See for example Antoncic \& Hisrich, 2003; McClelland, 1961; Marcketti, Niehm, \& Fuloria, 2006). An Australian dictionary definition of 'drive' implies an uncontrollable, compulsive force (Moore, 2004). Counterpointing this definition, this study found instead rather than "drive", entrepreneurs engaged in continuous social processes of constantly, and proactively pursuing. Subsequently, pursuing was deemed to be a more appropriate descriptor for the core category to explain the entrepreneurs' actions. Pursuing, then, reflects action involving persistent seeking and striving with purposeful intent to achieve sustainability. Relatedly, Sarkar, Echambadi and Harrison (2001) consider a proactive focus enables entrepreneurs to shape their environments through their own actions. Such a view of ongoing activity is also supported by Farrell and Twining-Ward's (2005) proposition that 'sustainable' implies constant evolution and adaptation that is never completed.

The following section elaborates on the sub-categories supporting the pursuing model. Key properties of each are identified as well as consideration of associated literature. Where relevant, emblematic comments from tourism entrepreneurs are included. The section commences with the causal entrepreneurial self, then the related conditions of pursuing information, legitimacy and futurity. Last, the contingent sub-category of social interaction is considered. 
Empirical material related to the tourism entrepreneurs' consideration of sustainable tourism aggregated around a causal component of an entrepreneurial 'self'. Covington (2001) reports an extensive literature related to a self-concept, encompassing who we think we are, derived from social structural features of role affiliations, as well as psychological character traits. An entrepreneurial self reflects these tourism entrepreneurs' consideration of their role in sustainable tourism and comprises major properties of 'vision' (a desirable goal), 'credibility' (securing reputable standing in the eyes of others), 'autonomy' (financial independence, including avoidance of restrictions), and 'moral reasoning' (a functioning rational entity) (Covington, 2001). A vision was expressed by all seven participants, and is exemplified by an entrepreneur involved in tour provision and his efforts to establish his credibility on the Gold Coast. "I dream my own Australian dream, when I first went out on my own, I had to tell people what I was doing so I made this brochure as a symbol of why I've done it, what's my experience, who I am, what I've done." Properties identified in psychological approaches to entrepreneurship identify traits of a need for achievement (nAch), credibility and autonomy, with more recent attention on personal values of honesty, and ethical behaviour (Kets de Vries, 1996; Stanworth \& Gray, 1991).

Abes, Jones and McEwen (2007) note that 'self' is multi-faceted, yet incorporates a core sense of values. The entrepreneurial self appears to be strongly influenced by moral reasoning and expectation of moral accountability as exemplified by this statement from an entrepreneur in the accommodation sector when considering the equity of operating a business. "So you've got to go upon a policy of fairness, reasonability to staff, and then do what is fair to the business and reasonable and fair to the guest." Gartner (1996) and Lynes and Dredge (2006) found that a decision process of environmental commitment is 
influenced by an individual's values, beliefs, understandings, and knowledge. These moral considerations also incorporate altruistic considerations of sustainability from an environmental perspective, illustrated by an entrepreneur in the attraction sector who sees potential for the tourism industry to demonstrate an environmentally sustainable business. "We can operate our businesses sustainably and we can also promote the area educationally, so that people can live in the environment without ripping all the trees down, without polluting the waterways, we should show the world that we can do that."

Philanthropy is based in altruism (Fennell, 2005) and these values are exemplified in the entrepreneurs' considerations of equity in operating a business in the tourism industry, donations to charitable causes, and altruistic considerations of sustainability from an environmental and social perspective. This may contribute to an entrepreneurial advantage, as Branwell and Alletorp (2001) believe that socially responsible behaviour improves competitiveness and profitability. The entrepreneurs explained their understanding of sustainable tourism through recounted actions that their 'self' engaged in to achieve their visions that were coded and subsumed into higher order conditional categories of pursuing information, pursuing legitimacy and pursuing futurity.

\section{Pursuing Information}

Pursuing information encompasses continuously seeking specific acquisition of knowledge for particular aspects of their ventures, or cumulative aggregation of general information that may be of use in the future. Aldrich and Cliff (2003) and Baron's (2004) view that entrepreneurs use information and experiences to identify business opportunities supports the condition of pursuing information. Research by Frederick, Kuratko and 
Hodgetts (2006) indicates seeking information is a continuous activity of 'environmental scanning,' and is a prerequisite to entrepreneurial planning. Pursuing information for the entrepreneurs involved seeking information regarding regulatory compliance procedures from federal, state and local governments, other tourism industry stakeholders, the local community, customers, family members and social acquaintances. Empirical material interpreted in this study generated properties of pursuing information that included four strategies of 'planning', 'bootstrapping', 'interacting', and 'limiting'.

Acquisition of relevant information was viewed as facilitating planning and resonated across all seven entrepreneurs' actions as an investment of time, and effort to achieve the sustainability of their businesses. These entrepreneurs apply planning techniques across broad areas as represented by the consideration of an entrepreneur in the accommodation sector. "I think everything to do with sustainability is about prior planning, and that's in all aspects whether it's financial, with the ownership, with the community, with the environment, its not something you are reactive to it is something you are proactive to."

Pursuit of this information was also acquired through 'bootstrapping', a wellrecognised entrepreneurial method of resource acquisition that does not involve a commercial transaction (Frederick et al., 2006). This is illustrated by the activities of an entrepreneur in the event sector of the tourism industry who was able to acquire information without incurring a cost. "I went up and spent a week in the [government department] offices, they charge two hundred dollars an hour to sit down with, I spent a week free of charge!" In pursuing information, entrepreneurs question the quality and expense of available professional information from consulting experts. In addition, they 
recognized, as an attraction provider commented: "What the text book says, and what actually happens in the real world at the grass roots level, are miles apart." Elsewhere, Larson (2000) comments on the importance of networks for entrepreneurs to gain information and establish relationships that will foster resource acquisition. The entrepreneurs in this study were acutely aware of this and recognized that in pursuing information, that they were the also pursuing legitimacy.

\section{Pursuing legitimacy}

Pursuing legitimacy is the second major condition of the core category of pursuing, and incorporates tourism entrepreneurs' efforts to ensure their tourism ventures 'comply' with the regulations of all levels of government. Payne and Joyner's (2006) study found external accountability that included political and legal responsibility was of distinct ethical value for entrepreneurs. Richter and Richter (1999) observed that tourism is controlled and maintained by public sector employees who administer the licensing, taxing, and zoning, yet note little evidence of political will or contingency planning to confront problems associated with expansion of tourism. A major concern for all entrepreneur participants was a perception that staff of these regulatory institutions thwarted tourism entrepreneurs' expected compliance by bureaucratic 'stonewalling', and this is exemplified by an entrepreneur in the restaurant sector. "That's what Council's obligation should be. Its not having to hold my hand through it all, but to tell me what they have planned for this area, and whether my project fits in with their plan. But no immediately they are adversarial." Stonewalling has been defined as being 'obstructive with evasive answers' (Moore, 2004). Dimensions of this property are broad, incorporating perceptions of irrelevant compliance rules, and an inflexible process that 
constricts pursuing activities. Payne and Dimanche (1996) note these uncontrollable legal and governmental influences as one of a number of domestic constraints in an international industry such as tourism. Similarly and specifically with regard to this study's context, Worthington and Dollery (2002) report that microeconomic reform recommendations in the Campbell Report (1981) advocate more consumer-focused efficient services. Continuing pressures from community and business to improve efficiency and effectiveness of Australian government services has produced little results apart from some technological cost efficiency in administration (Worthington \& Dollery, 2002). Another property of pursuing legitimacy was a perception of unreasonable 'forced compliance' incorporating a perception that rules imposed may not necessarily serve the best interests of the entrepreneurs or the community. This is demonstrated by the experience of an attraction sector entrepreneur's attempts to ascertain how some of the requirements they were required to implement were calculated. "We went to the [State government department] and asked how do we work this out because this can't possibly be right? But they go well um that's the model, and you can't argue with it. So I say how does it work? And they say we don't know!"

To 'achieve legitimacy', the tourism entrepreneurs employed several tactics including coping mechanisms such as capitulation to the process and expense, and manipulation by circumventing the bureaucratic process through direct appeal to elected government representatives. In addition, another tactic that several entrepreneurs used to achieve legitimacy were threats to abandon the Gold Coast region. Such threats can be considered as behavioral resistance in affect control theory (Smith-Lovin, 2001). Such resistance occurs when events threaten 'self' reference (such as an industriousness virtue), which in turn leads to negative emotions and withholding behaviors. The entrepreneurs in 
pursuing legitimacy were simultaneously intertwined with continuous processes of pursuing information and the following condition of pursuing futurity.

\section{Pursuing Futurity}

Pursuing futurity is a category of entrepreneurial action that incorporates properties of 'economic sustainability', 'consumer demand', 'industry stakeholders' and 'commission systems'. Economic sustainability is a long term, holistic view to maintain commercial viability of a tourism business. The competitive nature of the Gold Coast tourism industry is combined with relatively low return on investment, so considerations of costs in this context are imperative for survival. Seeking economic sustainability is also compounded by a need to employ staff and resulting employment legislation compliance. This links to pursuing legitimacy through compliance with pursuing information and results in a heavy burden as illustrated by an entrepreneur in the tour sector "I employ staff, they're all casual, and I have to worry about taxation, superannuation, leave, training, it's a long sad story, it's like an anchor." A further property of pursuing futurity is a need to achieve future consumer demand through marketing. Dimensions of this code include various levels of cooperation, consultation or membership with industry bodies established to handle promotion, such as regional and state tourism associations. Yaman and Gurel (2006) define collaboration in 'industry networks' as membership groups of similar businesses. Although Sarkar et al., (2001) recognise that entrepreneurs create value through associations that enable exploitation of business opportunities; for the tourism entrepreneurs in this study, participation in tourism associations failed to meet their expectations. Of particular note were their concerns regarding association funding usage and accountability. As noted by an entrepreneur in the transport sector when considering 
the performance of the Gold Coast industry association's marketing campaign. "Verygc was trendy, has it worked? No it hasn't worked because the product hasn't delivered, it cost a lot of money, and then the bastards say they're gonna make it a shopping capital .. its nonsense." Extant literature also reports similar concerns, for example, Dinan's (2000) critique of broad approach marketing campaigns in tourism, as lacking consumer information and not promoting sustainable tourism.

Related to the preceding property of consumer demand, pursuing futurity also comprises the property of interaction with industry stakeholders, such as, Chambers of Commerce, as well as formal and informal economic network alliances. Glancy, Greig and Pettigrew (1998) note that networking is a major component of service firms. Dredge (2006), however, cautions use of network theory to understand such alliances. According to Dredge, network theory is still underdeveloped and as yet fails to realize the complexity of networks especially the manifold sets of relations between actors, their levels of participation and interest. This study serves to support the complexity to which Dredge refers. The entrepreneurs in this study expressed strong concerns regarding commissions that are a component of 'doing' business on the Gold Coast. "Well it's a major part of the tourism business with legitimate commissions, nearly every tourism operator has to be paid commissions of some sort. It's not commission its just extortion I never realised the entrenchment up here, the backhanders, it's rife." Such commissions are viewed as a threat to sustainability as well as fostering an alleged endemic 'illegal' commission practice commissions. Literature reports that meeting illegal demands of high commissions with one partner has the purpose of preventing or making exchange with another less likely. Sarkar, et al., (2001) identify this phenomenon as 'strategic gridlock,' where unique proactive alliance activity leads to differences in sustainable performance. 
Tourism entrepreneurs in this study held similar views. One alleged that "So I learnt the Queensland way, its extortion, it's become very prevalent. Now within the industry they want the Federal government to outlaw it across the land and the government wont ... they're never gonna be changed, never gonna be addressed." The frustration and feeling of futility felt by tourism entrepreneurs is expressed.

To recapitulate, pursuing information is an activity the tourism entrepreneurs engaged in constantly and viewed as important for planning for sustainability of their ventures. Pursuing legitimacy related to their recognition of compliance with regulatory requirements for operating a business. Pursuing futurity incorporated the tourism entrepreneurs' concerns regarding tourism associations, networks, systems and practices operating among the Gold Coast tourism industry. The three conditions of pursuing information, pursuing legitimacy and pursuing futurity involved the tourism entrepreneurs in many social interactions.

\section{Social Interaction}

Social interaction is a contingent category incorporating properties of networking, involvement, reciprocity that enable or limit pursuing information, legitimacy, and futurity. Social interactions generate meanings and action through interpretations that reflect social processes determining a sense of mutual dependence in tourism environments (Forte, 2001). In this study, social interactions arise from two interrelated areas of contextual and situational conditions that are not fixed, but which are located and moulded by the encounter context and situational conditions of pursuing. 
Richter and Richter (1999) observe that exposing new problems in tourism is not encouraged and receives little credit. However, this study's entrepreneurs expressed an abhorrence of the alleged illegal commission practice and demanded that action be taken by regulating authorities. These perspectives mirror Macbeth's (2005) belief that true sustainability requires adherence to sound ethical rules.

Pursuing Sustainable Tourism and Ethics

In the course of developing the grounded theory model of pursuing, the role of ethics in tourism entrepreneur decision-making became evident, especially in the conditions of pursuing legitimacy and futurity. Ethics is defined by Kuratko and Welsch (2004) as "a set of principles prescribing a behavioral code that explains what is good and right or bad and wrong” (p. 78). Inherent in these entrepreneurs' discourse was an understanding of sustainable tourism informed by a praxis of reasoning (phronesis) characterized by questioning the ethics of certain situations. Further extant literature notes many entrepreneurs are highly principled and act ethically, and value integrity, honesty and a strong work ethic (Barbee, 2005; Gobel, 2000). Elsewhere Morris, et al., (2002) observe that entrepreneurs demonstrate high ethical standards due to a strong locus of control, (LOC) that is reliant on personal ethical standards. With regard to this study, ethical concerns related to social responsibility and environmental concerns were integral to these seven tourism entrepreneurs' lived experiences of pursuing. An accommodation focused entrepreneur expressed his views of social accountability. "You know we should worry about future generations. Look it would be really rather interesting, to have that social awareness as part of any development that goes for a tourism application." 
The seven tourism entrepreneurs involved in this study tended to consider sustainable tourism based on four antecedents identified by Lepoutre and Heene's (2006): context, personal values and actions, resources of the firm, and industry context characteristics. These appear as properties of a basic social process of pursuing.

\section{TOWARDS A CONCLUSION: A GROUNDED THEORY OF PURSUING}

This study's grounded theory methodology enabled the generation of a basic social process of pursuing through conceptualisation and constant comparison of empirical material related to the seven tourism entrepreneurs' understanding and practices of sustainable tourism. In the context of a complex Gold Coast tourism industry, based on the lived experiences of those entrepreneurs, an entrepreneurial self engages in pursuing activities for establishment and maintenance of a sustainable tourism venture. These activities are related to conditions or events associated with pursuing information, legitimacy and futurity. In the course of pursuing, the entrepreneurs engaged in ethical decision making which was contingent and influenced by numerous complex social interactions as well as their lived experiences of those interactions. The consequences of pursuing sustainable tourism generated a number of ethical dilemmas that had related consequences for the praxis of sustainable tourism by the entrepreneurs.

This research represents a first step to developing a framework conceptualising tourism entrepreneurs' lived experiences, understandings and practices of sustainable tourism. A grounded theory perspective acknowledges that all understanding is subject to continuing reflection, transformation and reinterpretation. Recognising tourism entrepreneurs' activities instigate much economic growth on the Gold Coast, pursuing, as 
an explanatory framework offers directions for future research. Research directions suggested by this research are based on tourism entrepreneurs' perception of regulating authorities and a need to examine perspectives of current government protocols and particularly government employees' understanding of sustainable tourism as there appears ethical issues related to work ethic, customer service and accountability that hinders sustainable tourism.

A number of other avenues associated with economic sustainability for Gold Coast tourism entrepreneurs arose in the course of undertaking this study. These include research into the legal and alleged illegal commission systems that appear to be a 'norm' within the specific context of the Gold Coast tourism industry. An extended follow-up study with a larger group of tourism entrepreneurs. This should be complemented with a quantitative survey to further explore entrepreneurs' lived experiences of establishing a tourism venture. This would develop a more comprehensive understanding of issues inhibiting facilitation of sustainable tourism. Finally, broader scaled industry-related lived experiences research would further develop this pursuing model. Such research should contextualize the socio-cultural backgrounds of entrepreneurs including gender considerations.

[5210 word count] 
References

[1568 word count]

Abes, E. S., Jones, S. R., \& McEwen, M. K. (2007). Reconceptualizing the model of multiple dimensions of identity: The role of meaning-making capacity in the construction of multiple identities. Journal of College Student Development, 48(1), $1-22$.

Aldrich, H. E., \& Cliff, J. I. (2003). The pervasive effects of family on entrepreneurship: toward a family embeddedness perspective. Journal of Business Venturing, 18(5), 573-596.

Antoncic, B., \& Hisrich, R. D. (2003). Clarifying the intrapreneurship concept. Journal of Small Business and Enterprise Development, 10(1), 7-24.

Barbee, B. (2005). Ethics of entrepreneurship. Baylor Business Review, 22(2), 42-45.

Baron, R. A. (2004). Opportunity recognition. Insights from a cognitive perspective. In J. E. Butler (Ed), Opportunity identification and entrepreneurial behavior (pp. 47-73). Greenwich, CT: Information Age Publishing.

Baumol, W. J. (2004). On entrepreneurship, growth and rent-seeking: Henry George updated. American Economist, 48(1), 9-16.

Becken, S., \& Patterson, M. (2006). Measuring national carbon dioxide emissions from 
tourism as a key step towards achieving sustainable tourism. Journal of Sustainable Tourism, 14(4), 323-338.

Bramwell, B., \& Alletorp, L. (2001). Attitudes in the Danish tourism industry to the roles of business and government in sustainable tourism. International Journal of Tourism Research, 3(2), 91-103.

Bramwell, B., \& Lane, B. (2002). The Journal of Sustainable Tourism: The first ten years. Editorial. Journal of Sustainable Tourism, 10(1), 1-4.

Branco, M. C., \& Rodrigues, L. L. (2006). Corporate social responsibility and resource-based perspectives. Journal of Business Ethics, 69, 111-132.

Buckley, R. (2002). Surf tourism and sustainable development in Indo-Pacific island. II. Recreational capacity management and case study. Journal of Sustainable Tourism, 10(5), 425-442.

Buckley, R. (1996). Sustainable tourism: Technical issues and information needs. Annals of Tourism Research, 23(4), 925-928.

Campbell Report. (1981). Australian financial system : final report of the Committee of Inquiry, September 1981. Committee of Inquiry into the Australian Financial System. Canberra : Australian Government Publishing Service

Chapman, M. (2000). 'When the entrepreneur sneezes, the organization catches a 
cold': A practitioner's perspective on the state of the art in research on the entrepreneurial personality and the entrepreneurial process. European Journal of Work and Organizational Psychology, 9(1), 97-101.

Charmaz, K. (2006). Constructing grounded theory. A practical guide through qualitative analysis. Thousand Oaks, CA: SAGE Publications.

Charmaz, K. (2005). Grounded theory in the $21^{\text {st }}$ Century. Applications for advancing Social Justice Studies. In N. K. Denzin, \& Y. S. Lincoln. (Eds.). The Sage handbook of qualitative research. ( $3^{\text {rd }}$ ed.) (pp. 507-535). Thousand Oaks, CA: Sage Publications, Inc.

Covington, M. V. (2001). The science and politics of self-esteem. . In T. J. Owens, S. Stryker \& N. Goodman (Eds.). Extending self-esteem theory and research. (pp. 351-374). Cambridge, UK: Cambridge University Press.

Dery, R., \& Toulouse, J. M. (1996). Social structuration of the field of entrepreneurship. A case study. Revue Canadienne des Sciences de L'Administration, 13(4), 285-305.

Dinan, C. (2000). Social marketing and sustainable tourism - is there a match? International Journal of Tourism Research, 2(1), 1-14.

Dredge, D. (2006). Networks, conflict and collaborative communities. Journal of Sustainable Tourism, 14(6), 562-581. 
Farrell, B., \& Twining-Ward, L. (2005). Seven steps towards sustainability: Tourism in the context of new knowledge. Journal of Sustainable Tourism, 13(2), $109-122$

Faulkner, B., \& Tideswell, C. (1997). A framework for monitoring community impacts of tourism. Journal of Sustainable Tourism, 5(1), 3-28.

Fennell, D. A. (2005). Tourism ethics. Buffalo, NY: Channel View Publications.

Font, X., \& Harris, C. (2004). Rethinking standards from green to sustainable. Annals of Tourism Research, 31(4), 986-1007.

Forte, J. A. (2001). Theories for Practice. Symbolic Interactionist translations. Maryland, USA: University Press of America Inc.

Frederick, H. H., Kuratko, D. F., \& Hodgetts, R. M. (2006). Entrepreneurship: Theory, process, practice. Sydney, Australia: Thomson.

Gartner, W. C. (1996). Tourism Development. Principles, processes and policies. New York: Van Nostrand Reinhold.

Glancy, K., Greig, M., \& Pettigrew, M. (1998). Entrepreneurial dynamics in small business service. International Journal of Entrepreneurship Behaviour \& Research, 4(3), 249-263. 
Glaser, B. G. (1978). Theoretical sensitivity. Advances in the methodology of grounded theory. California: The Sociology Press.

Glaser, B. G. (1992). Basics of grounded theory analysis. Emergence vs. forcing. Mill Valley, CA: Sociology Press.

Glaser, B. G. (1998). Doing grounded theory: Issues and discussions. Mill Valley, CA: Sociology Press.

Glaser, B. G. (2001). Conceptualization contrasted with description. Mill Valley, CA: Sociology Press.

Glaser, B. G. (2007). Doing formal grounded theory: a proposal. Mill Valley, CA: Sociology Press.

Glaser, B. G. \& Strauss, A. L. (1967). The discovery of grounded theory. Strategies for qualitative research. New York: Adline de Gruyt.

Glover, R. E. (1998). Tourism as Economic Development. Retrieved February 26, 2005, from http://www.economicdevelopment.net/tourism/.

Gőbel, S. (2000). Klaus B: The success story of an entrepreneur - a case study. European Journal of Work and Organizational Psychology, 9(1), 89-92. 
Gold Coast Tourism. (2009). Statistics page. Retrieved December3, 2009, from http://www.goldcoast.qld.gov.au/.

Haley, A. J., Snaith, T., Miller, G. (2005). The social impacts of tourism a case study of Bath, UK. Annals of Tourism Research, 32(3 ), 647-668.

Hemingway, C. A. (2005). Personal values as a catalyst of corporate social entrepreneurship. Journal of Business Ethics, 60, 233-249.

Hill, J., \& McGowan, P. (1999). Small business and enterprise development: questions about research methodology. International Journal of Entrepreneurial Behaviour \& Research, 5(1), 5-18.

Hisrich, R. D., \& Peters, M. P. (1998). Entrepreneurship. (4 ${ }^{\text {th }}$ ed.). Boston, Massachusetts: Irwin/McGraw Hill.

Holden, A. (2003). In need of new environmental ethics for tourism? Annals of Tourism Research, 30(1), 94-108.

Holden, A. (2005). Achieving a sustainable relationship between common pool resources and tourism: The role of environmental ethics. Journal of Sustainable Tourism, 13(4), 339-352.

Hollinshead, K. (1988). A sunny place for shady people: The real Gold Coast. Story by 
Michael Jones. Allen \& Unwin. Sydney. Annals of Tourism Research, 15(3), 449453.

Hollinshead, K., \& Jamal, T. B. (2007). Tourism and the third ear; Further prospects for qualitative inquiry. Tourism Analysis, 12(1-2), 85-129.

Honey, M. (2003). Protecting Eden: Setting green standards for the tourism industry. Environment, 45(6), 8-22.

Jennings, G. (2001). Tourism Research. Milton, Qld: John Wiley \& Sons Australia.

Jennings, G. R. (2005). Interviewing: a focus on qualitative techniques. In B. Ritchie, P. Burns, \& C. Palmer. (Eds.). Tourism Research Methods. Oxfordshire, UK: CAB International.

Jennings, G. R., \& Junek, O. (2007). Grounded theory: Innovative methodology or a critical turning from hegemonic methodological praxis in tourism studies? In G. R. Jennings. The critical turn in Tourism studies: Innovative research methodologies. (pp. 199-212). Elsevier Ltd.

Kets de Vries, M. F. R. (1996). The anatomy of the entrepreneur: clinical observations. Human Relations, 49(7), 853-883.

Kuratko, D. F. (2006). A tribute to 50 years of excellence in entrepreneurship and small business. Journal of Small Business Management, 44(3), 483-583. 
Kuratko, D. F., \& Welsch, H. P. (2004). Strategic entrepreneurial growth. (2 ${ }^{\text {nd }}$ ed.). USA: Thomson South Western.

Landstrőm, H. (2005). Pioneers in entrepreneurship and small business research. USA: Springer Science and Business Media.

Lepoutre, J., \& Heene, A. (2006). Investigating the impact of firm size on small business social responsibility: A critical review. Journal of Business Ethics, 67, 257-273.

Lincoln, Y. S., \& Guba, E. G. (1985). Naturalistic inquiry. Beverley Hills, CA: SAGE Publications Inc.

Lynch, P., \& MacWhannell, D. (2000). Home and commercialized hospitality. In C. Lashley \& A. Morrison. (Eds.). In Search of Hospitality: Theoretical perspectives and debates. Oxford: Butterworth-Heinemann. (pp. 100-117).

Lynes, J. K., \& Dredge, D. (2006). Going green: Motivations for environmental commitment in the airline industry. A case study of Scandinavian Airlines. Journal of Sustainable Tourism, 14(2), 116-138.

Macbeth, J. (2005). Towards an ethics platform for tourism. Annals of Tourism Research, 32(4), 962-984. 
Marcketti, S. B., Niehm, L. S., \& Fuloria, R. (2006). An exploratory study of Lifestyle entrepreneurship and its relationship to life quality. Family and Consumer Sciences Research Journal, 34(3), 241-259.

McClelland, D.C. (1961). The Achieving Society. Princeton, NJ: Van Nostrand.

McCool, S. F., \& Lime, C. W. (2001). Tourism carrying capacity: Tempting fantasy or useful reality? Journal of Sustainable Tourism, 9(5), 372-386.

Montanye, J. A. (2006). Entrepreneurship. The Independent Review, 10(4), 547-570.

Moore, B. (Ed.). (2004). The Australian Concise Oxford Dictionary. (4 ${ }^{\text {th }}$ ed.). Melbourne: Oxford University Press.

Morris, M. H., Schindehutte, M., Walton, J., \& Allen, J. (2002). The ethical context of entrepreneurship: Proposing and testing a developmental framework. Journal of Business Ehtics, 40(4), 331-362.

Morrison, A., \& Teixeira, R. (2004). Small business performance: a tourism sector focus. Journal of Small Business and Enterprise Development, 11(2), 166-173.

Patterson, T., Bastianoni, S., \& Simpson, M. (2006). Tourism and climate change: Two way street, or vicious/virtuous circle? Journal of Sustainable Tourism, 14(4), 339-348. 
Patton, M. Q. (1990). Qualitative Evaluation and Research Methods. London: Sage.

Payne, D., \& Dimanche, F. (1996). Towards a code of conduct for the tourism industry: An ethics model. Journal of Business Ethics, 19(9), 997-1008.

Payne, D., \& Joyner, B. E. (2006). Successful U. S. entrepreneurs: Identifying ethical decision-making and social responsibility behaviors. Journal of Business Ethics, 65, 203-217.

Pearce, D. G. (2001). An integrative framework for urban tourism research. Annals of Tourism Research, 28(4), 926-946.

Richter, L. K., \& Richter, W. L. (1999). Ethics challenges: Health, safety and accessibility in international travel and tourism. Public Personnel Management, 29(4), 595-616.

Russell, R., \& Faulkner, B. (2004). Entrepreneurship, chaos and the tourism area lifecycle. Annals of Tourism Research, 31(3), 556-579.

Sarkar, M. B., Echambadi, R., \& Harrison, J. S. (2001). Alliance entrepreneurship and firm market performance. Strategic Management Journal, 22(6/7), 701-711.

Smith-Lovin, L. (2001). Social psychology. In J. R. Blau (Ed.). The Blackwell companion to sociology. (pp. 407-420). Massachusetts: Blackwell Publishers. 
Stanworth, J., \& Gray, C. (Eds.). (1991). Bolton 20 years on. The small firm in the 1990s. London: Paul Chapman Publishing Ltd.

Thompson, J. L. (2004). The facets of the entrepreneur: identifying entrepreneurial potential. Management Decision, 42(2), 243-258.

Weaver, D. B., \& Lawton, L. J. (2001). Resident perceptions in the urban - rural fringe. Annals of Tourism Research, 28(2), 439-458.

Welford, R., Ytterhus, B., \& Eligh, J. (1999). Tourism and sustainable development: An analysis of policy guidelines for managing provision and consumption. Sustainable Development, 7(4), 165-177.

Wempe, J. (2005). Ethical entrepreneurship and fair trade. Journal of Business Ethics, $60,211-220$.

Wilkinson, P. F. (2007). Community management in developing economies. Annals of Tourism Research, 34(2), 549-550.

Worthington, A. C., \& Dollery, B. E. (2002). Empirical analysis of productivity in Australian local government, 1993/94 to 1995/96. Public Administration Quarterly, 26(1/2), 234-270.

WTO. (1999). Tourism Satellite Account (TSA). The Conceptual Framework. 
Madrid. World Tourism Organisation (2005). Facts and figures. Historical perspective of world tourism. Retrieved November 12, 2005, from http://www.world.tourism.org/facts/eng/historical

Yaman, H. R., \& Gurel, E. (2006). Ethical ideologies of tourism marketers. Annals of Tourism Research, 33(2), 470-489.

Figure 1: Examples of Questions

Could you tell me about how you came to start this venture?

Tell me what you think 'sustainable tourism' means?

What do you think are the most important ways to implement sustainable tourism?

Figure 2: A grounded theory of pursuing

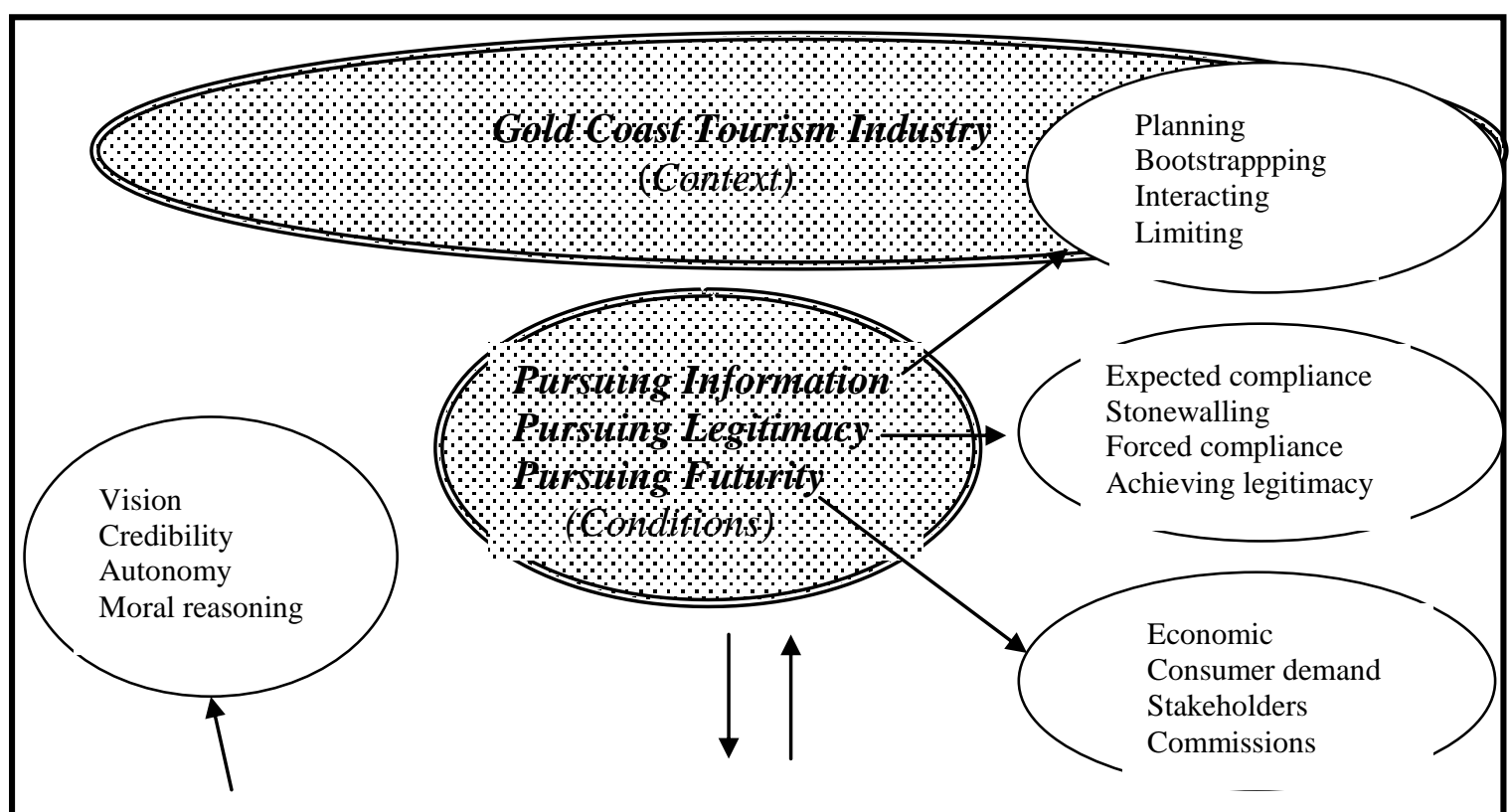




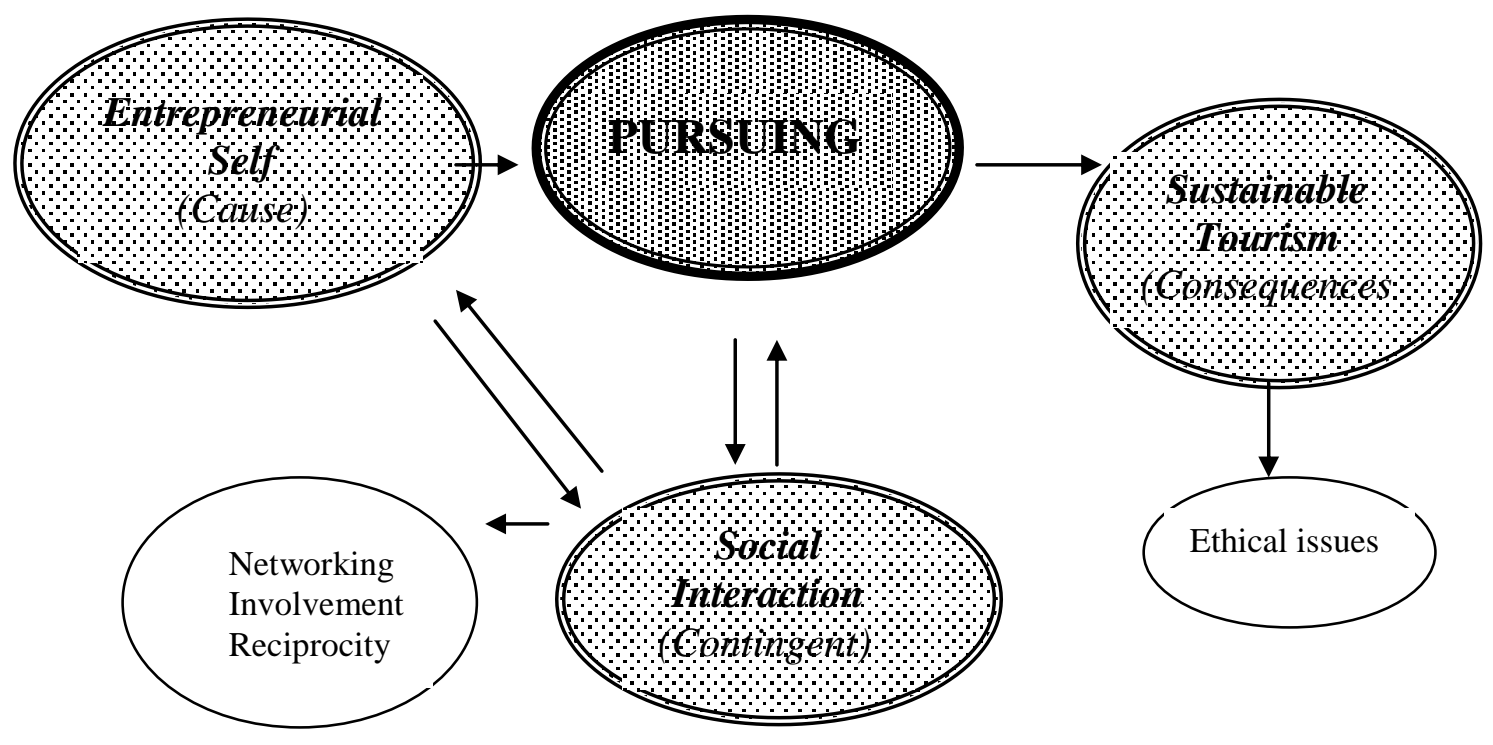

